\title{
The Nigeria-Biafra War, Oil and the Political Economy of State Induced Development Strategy in Eastern Nigeria, 1967-1995
}

\section{Chima J. Korieh}

University of Nigeria

\begin{abstract}
In recent years, the low agricultural productivity, food insecurity and environmental degradation have become more apparent in many African societies. These trends have threatened the farmers' ability to increase productivity and to practice sustainable agriculture. The crisis in agricultural productivity is structural as it is demonstrated by the impact of the Nigeria-Biafra War and the emergence of the petroleum industry in the 1970s. This paper reveals that the agricultural crisis in many parts of sub-Saharan Africa has been misunderstood because the analysis often ignores how the ideology of state development interacted with local ecological conditions and peasants' actions to structure the changes in peasant economies. In the case of Eastern Nigeria, the Nigeria-Biafra War (1967-1970) and the emergence of the petroleum industry as the most important contributor to national GDP challenged the economic ideology that sought to use agriculture as a driver of economic development.
\end{abstract}

African agriculture has witnessed significant decline in recent years. In the 1960s, Africa was a self-sufficient in food as well as a net food exporter. The exports averaged 1.3 million tons a year up to 1970 . In recent years, however, the continent imports over 25 per cent of food stuff. It has been revealed that Nigeria is the largest importer of rice in the world (2013). Hunger and famine have become recurrent problems especially in the Horn of Africa, the Sahel, Southern Africa, and Central Africa (Bello 2008). From 1985, for example, an estimated

Social Evolution \& History, Vol. 17 No. 1, March 2018 76-107

(C) 2018 'Uchitel' Publishing House

DOI: $10.30884 / \mathrm{seh} / 2018.01 .05$ 
10 million Africans left their homes and fields because they were unable to support themselves. An additional 20 million were reported to be at risk of debilitating hunger (Timberlake 1985). Numerous World Bank reports since the 1980s have indicated an overall pattern of severe economic deterioration and stagnation manifested in food security problems and low levels of growth in the agricultural sub-sector (World Bank 1981, 1984, 1989).

This article examines the nature of agricultural development policy and the impact of structural changes such as the Nigeria-Biafra War and the development of the petroleum industry in Eastern Nigeria in the post-independence era, from 1960 to 1995. Essentially, analyzing this period enables us to examine continuity as well as change in the agricultural economy under the indigenous political authority. I suggest that despite the modernization policies pursued by the state, structural changes resulting from the Nigeria-Biafra Civil War from 1967 to 1970, the expansion of the petroleum industry in the post-civil war period and related environmental and demographic factors were important in rural transformation and the agricultural involution in Eastern Nigeria. Local historical studies, including this one, are particularly useful being corrective to national aggregates since the local specificity can, as Mary Tiffin wrote, 'bring to light a pattern of failure (or success) which indicates intractable problems or the need for specific efforts to overcome them' (Tiffen 1976).

The state intervention in agriculture in Eastern Nigeria can be traced to the colonial period and the encouragement of export production. The production of palm oil and kernels for the export market opened completely new vistas to the government as well as rural producers. The expansion of export production during the colonial period was achieved by a combination of political and economic control. These measures led to new forms of production relations, land use, adaptation of new agricultural technologies, and restructuring of the economy.

The indigenization of agricultural policy in Nigeria started in 1954, when the country still remained under British rule. The Constitution of 1954 ceded aspects of economic planning, particularly agricultural policy, to the regional governments. The nature of the local political economy in this period made it necessary for the regions to depend largely on agriculture as the major source of state revenue and private income. For both the national and regional governments, agriculture still loomed large, contributing about 60 per cent of national income and subsistence for over 70 per cent of the population. In the 
Eastern Region, in particular, agriculture was considered as the most important route to economic development and increased welfare for the people (Eastern Nigeria: Official Document 1962: 3-8). The government's involvement in and funding of agricultural projects was based on the assumption that government could increase both the quantity and quality produced. ${ }^{1}$ Like the colonial authorities, the regional authorities challenged the ability of local peasants to assimilate agricultural development.

Towards the end of the colonial period, the government faced the problem of how to fund its development programmes and the general social welfare of the people. In Eastern Nigeria, the need to generate more revenue for development purposes led the regional government to intensify agricultural production. When Nigeria obtained political independence in 1960, the Eastern Region continued to encourage the expansion of export production. Largely, the post-colonial government continued with colonial agricultural policies, but political independence made a big difference. It offered new possibilities of incorporating indigenous ideas and new policies. That shift in the nature of agricultural policies and their impact on peasants became clearer with the introduction of large-scale state plantations and farm settlements starting from 1960. The nature of governmental agricultural policies and intervention in rural economy contributed to the expansion of the productive capacity of rural farmers. However, at the same time, the top-down approach of the government's development agenda generated a crisis in the rural economy.

Historians of agrarian change in Africa generally view the 1960s as the years when state intervention in peasant agriculture became more prominent and generated the agricultural crisis that matured in the 1980s (Ayittey 1998; Berry 1993: 77). Roland Oliver argued that 'perhaps the greatest misfortune of the modern African nations was that their approach to independence coincided with a period when it was generally believed that the way to a better future lay through more and longer-term state planning, with its implementation led by a large and ever-expanding public sector' (Oliver 1999). The validity of this claim requires a case-by-case assessment of the economic policies adopted during the post-independence period. Why, for instance, did the regional government in Eastern Nigeria establish large-scale plantations? What ideological and economic debates shaped the state agricultural policy in the region during what can be aptly termed the plantation era? An approach that takes into account the nature of state policy in this period provides important insights into the nature and dy- 
namics of agricultural change and farmers responses. Although state policy was an important factor of agricultural transformation, the population of the region, the ecology and peasant initiatives were all fundamental to the nature of agricultural change in the post-independence period.

The emergence of Eastern Nigeria as an internally self-governing region brought with it a consolidation of the Department of Agriculture, Fisheries, Forestry and Veterinary Services and Produce Inspection into a Ministry of Agriculture (MOA). The establishment of the MOA heralded the formulation of an elaborate agricultural policy with the objective of maximizing productivity through a wise utilization of the natural assets of the region. The government was of the view that it had a significant role to play in mapping the course of future development and utilization of resources. In formulating the Eastern Nigeria Development Plan for the years 1962-1968, the government emphasized what it described as the 'predominantly primitive state of agricultural production', and 'peasant resistance to sudden change.'

During this period, the stimulation of production of export crops by local farmers on their own land was challenged since they faced more direct demands on their land and labour. Like its colonial predecessor, the successor government continued the policy of investing in the export sub-sector of agricultural sector in an attempt to generate the income needed for economic and industrial development. Although rural farmers expanded production to meet their cash needs, the continued expansion of agriculture depended upon new systems of production and more direct state participation. The government's new agricultural strategy is reflected in the allocation of a significant part of the development budget to agriculture. After independence, the reform-minded Premier of the Eastern Region, M. I. Okpara, launched one of the most ambitions agricultural programmes in Nigeria. Sometimes referred to as the 'Okpara Revolution', the Premier's vision was an agricultural revolution that would consist of large-scale state plantations in addition to peasant production. In the immediate postcolonial period Nigeria witnessed a rapid expansion of state initiated agricultural projects. The new elite continued with many colonial policies but broke with an important one - the rejection of the plantation system.

Between 1960 and 1966, the oil palm production remained relatively large. The revenues received by the farmers were high enough to warrant investment in trading and transportation. The penetration of roads and lorries into remote villages promoted the expansion of trade 
as well as encouraged urban migration. The importance of yams, cassava and other farm products as sources of cash, also increased with urban growth. This reduced rural dependence on export production, although oil palm remained an important source of cash. However, the contradictions inherent in the plantation system and the neglect of peasants' interests combined with environmental and demographic factors which push peasants off the land. The effects of these factors overwhelmed the efforts of peasants to meet their food and cash needs.

A different set of factors that affected the capacity of both farmers and the regional governments to increase agricultural productivity emerged because of the civil war from 1967 to 1970. The war had a significant effect on the agricultural economy of the region. The political events that developed because of the war impinged on the fundamental roots of rural life. The expansion of the petroleum industry in this period further generated crises in the rural agricultural economy. The civil war, the expansion of the petroleum industry, and the global economy in this period pushed agriculture into the backwaters of the regional economy. Largely, rural farmers responded to the agricultural crisis by adopting new strategies to ensure food security. While the people in the region have historically employed some of these survival strategies, they have been more aggressively pursued since the 1970s as the rural population expands on non-agricultural income generation. These survival strategies, however, have continued to be influenced by local social and cultural systems and a very strong kinship structure.

\section{WAR, AGRICULTURE, AND EASTERN NIGERIA FARMERS}

By 1966, Nigeria was in a political crisis that culminated in the Biafra-Nigeria Civil War in 1967. The war was the culmination of the political problems created by the colonial authorities in Nigeria when Fredrick Lugard merged different parts of the territory in 1914. The problem was further complicated by the 1954 Constitution, which introduced regionalism in Nigeria. ${ }^{2}$ The division of the country into three provinces - Western, Eastern and Northern provinces - introduced ethnic and regional parochialism that resulted in a military coup and counter coup in 1966. The various regions competed against each other for political and economic development. Michael Watts argues that the outbreak of the war 'must ultimately be seen in relation to the contradictory centripetal and centrifugal forces that were generated by 
the disintegration of the regional economic base and the centralising tendency provided by the rise of petroleum production' (Watts 1983: 376). Other Nigerians also resented the aggressive nature of Igbo entrepreneurship. A stable political situation guaranteed Igbo emigration and entrepreneurial activities throughout the country. As long as this prevailed, the constraints imposed on the Igbo agricultural economy were somewhat mitigated. The Igbo were tolerated until the political crisis and coups of 1966 led to the massacre of thousands of Igbo men, women, and children in Northern Nigeria and the flight of many thousands more.

On 30 May 1967, Col. Odumegwu Ojukwu, the military governor of the Eastern Region, declared the independent Republic of Biafra. A predominantly Igbo territory, the declaration and the civil war that followed became one of the most important factors of change in Eastern Nigeria in the post-independence era. The war led to the introduction of new agricultural development programs that sought to deal with the food insecurity that emerged in the regions. The structural poverty and insecurity that emerged during the war indeed shows that many parts of Eastern Nigeria were already food insecure. The civil war also fundamentally altered the economic and social value attached to farming.

The decline in productivity in this period was the result of both political actions on the part of the Nigerian government and factors beyond the control of local farmers. The Nigerian government used food as a weapon of war. The strategy was to starve the Igbo to death; a strategy that the Nigerian government hoped would lead to the quick demise of Biafra. The federal government tightened control over the Igbo territories and forced the Igbo to look inwards for their survival. The view of the Nigerian government and the use of starvation as a 'legitimate' weapon of war. This strategy included blocking Biafran food corridors behind federal lines. The strategy also included halting international relief. To this effect, the federal government shot down a Red Cross plane bringing food to the trapped Biafrans. The Red Cross, the largest relief agency in Biafra, claimed it could no longer fly into Biafra after it was shot down. Without it, Biafra lost over $50 \%$ of its food and relief supply. With the Red Cross blocked, Biafra faced a serious food crisis that led to the death of over 1 million Igbos.

The restriction generated food scarcity in Eastern Nigeria, given the population density and the dependence on other parts of Nigeria for some of its food needs. Most importantly, the war demonstrated both the problems that many Igbo already faced before the war and the 
resilience of the peasantry. The region is what I have referred to as a food-reserve-deficit economy. It was one in which the agricultural economy did not permit significant reserve of produce for use in lean times. In central Igboland, in particular, rural producers supported their own production with what they bought in the market. This way, many groups in Igboland prevented deprivation and ensured a normal food supply in an average year. Mbaise area, for example, established strong trade links with the Etche and other regions for their supply of fish, salt and cassava. Trade among different parts of Igboland alleviated the food scarcity that many parts of the region faced. The displacement of farmers from the agriculturally rich areas of Abakiliki, Nike and Afikpo exacerbated the scarcity of rice and yams. The war also jeopardised trade with other regions outside Igboland. This threatened the survival of many Igbo people. Military activities made it impossible for the population to farm or engage in normal economic activities.

Many parts of Eastern Nigeria had reached a critical population density in terms of area cultivated per unit of population before the war began. Although Igboland remained predominantly rural, survival already depended on large-scale out-migration from Igboland. This way, the remaining population achieved a level of agricultural sustainability and obviated the limits imposed by the population and the physical environment to agricultural growth. The war was challenging for many families and the region. An estimated 2 million Igbo people returned to the Eastern Region during the crisis. The rural economy was stretched to its limits as the returnees cramped into a very small land area. ${ }^{3}$ Writing on the refugees returning to the Eastern Region during the pogrom, a correspondent of the London Observer of 16 October 1966 compared it to the in-gathering of exiles into Israel after the end of World War II.

The people of Eastern Nigeria have responded in many ways to the impact of the environment and the population on agriculture. As David Cleveland observed, the debate on the relationship between agriculture and the environment has been cast in terms of 'optimists' or Boserupians, who see increasing population as the cause of changes in the agricultural system, which increase carrying capacity, and the 'pessimists' or Malthusians, who see increasing population as decreasing human carrying capacity (Cleveland 1998). However, such macrodemographic theory overlooks local control and how structural changes induced by war upset such mechanisms of control in a very short amount of time. 
Indeed, rural dwellers have historically exhibited ingenuity in increasing the carrying capacity of their limited agricultural potentialities, but their capacity to do so became limited during the war. The strategy of Eastern Nigeria farmers included storing a substantial part of their harvest, especially seed yams and cocoyams, for the next planting season. This ensured their food security and continued reliance on agriculture as the main economic activity of the rural areas. In the face of war and uncertainty, farmers in many parts of Eastern Nigeria survived by eating their seed yams and cocoyams. Amid famine and food insecurity, there were few economic opportunities. This, however, did not abate the need to cultivate the land, but the insecurity of the war made it practically impossible for many to cultivate their farms.

Many rural dwellers were forced by the circumstances of the war to support relatives who were forced to return home in increasing numbers from Northern Nigeria. Thus, Eastern Nigerians faced a crisis in this period not solely in terms of their inability to carry out normal farming activities but also in the added burden, which the social relations imposed on them. Informants, however, saw their actions in both rational and utilitarian terms, for many of the returnees had supported their folks at home with their earnings in times of peace.

\section{BIAFRA GOVERNMENT RESPONSE TO THE AGRICULTURAL DILEMMA}

Prior to the civil war, agricultural development emphasized increased production of cash crops for export through the distribution of improved seeds and the expansion of the area under cultivation. However, while over $80 \%$ of the population depended on agriculture and the sector contributed over $50 \%$ of GDP, only $13.6 \%$ or 183.8 million naira of the total capital expenditure of 1,353 million naira was allocated to primary production (including crops, livestock, forestry and fishing). The figure, Iyegha argues, did not reflect the emphasis placed on the agricultural sector in the preamble to the document and certainly does not mark the beginning of a truly committed indigenous effort to achieve a balanced development of the economy (Iyegha 1988: 118). The civil war, however, coincided with the period of the first National Development Plan, 1962-1968 (later extended to 1970), which was the platform for the articulation of Nigeria's development. Very high priority was given to agriculture at the national and regional levels of government.

The Eastern Region established plantation schemes and farm settlements under this development plan. These agricultural schemes 
formed the backbone of the Biafra Development Corporation (BDC) and the agricultural development programmes embarked upon during the civil war. However, when the Eastern Region seceded in 1967, the agricultural programmes of the Region had not started to bear fruit. To ensure the survival of Biafra, the government stressed food crop production. This new policy was adopted in response to the food crisis that emerged because of the war and the difficulties of marketing export crops. Throughout the war, the Biafran government tenaciously pursued a policy that would ensure that the population kept itself and the army fed. On the part of the Igbo, many made enormous sacrifices 'for the love of the Biafran nation'. If there was mystery about how the Igbo people survived the war, there was none about the hardship they faced. Despite the disruption of the bureaucratic system in the Eastern Region following the war, the ingenuity of the Biafran leadership, the army, civil authority, and peasants combined to ensure the survival of most the Igbo population until the end of the war.

The Biafra Development Corporation continued with the functions of the ENDC, including the co-ordination of the plantation scheme and cash crop production. The main task of the BDC, however, was to solve the problems that emerged because of the civil war. It acted as the coordinating body for food production and the overall agricultural industry in general. The objectives of the Corporation included:

(a) To convert several acres of acquired virgin forest land into cultivatable lands for immediate production of food crops needed to feed the teeming population and the production of livestock feed;

(b) The production of food crops to raise immediate cash revenue and plough back any surplus into the tree crops programme (NAE ESIALA 1968a).

The emphasis on food production in Biafra represented a major departure from the previous emphasis on export production. Beginning in 1967, the Corporation began to utilise some of the land in the region acquired for plantations for maize, rice, onion, tomato, and groundnut production. To meet the protein needs of the region, which had formerly depended on the north, the Corporation embarked on pig and poultry production (Ibid.). Although the effects of the war imposed conditions significantly different from what the state and peasants had faced in the past, the state's attitude to agriculture and its poor record on support for rural farmers changed very little under the Biafran government. 
The need to develop a strategy for food production became critical because of the war. This led to the establishment of the Food Production Directorate. The Food Production Directorate was charged with the task of producing maize, rice, onions, tomatoes, and groundnuts in addition to pigs and poultry (NAE ESIALA 1968a). The members of the BDC and the Food Directorate carried out information campaigns as part of the sustained effort to increase the food supply in Biafra. The Directorate hoped to 'co-ordinate the activities of government ministries, public boards and corporations with interest in land development for food production purpose' (Ibid.). Members of the Food Production Directorate were drawn from the private sector and from government ministries that had interest in agricultural and food production including the Ministry of Agriculture, Rural Development, Forestry and Animal Health, Lands and Survey, Universities, Biafra Development Corporation, and the Niger Delta Development Board.

This new effort, however, was not a systematic attempt by the government to reform agriculture. The government recognized the need to mobilize all government agencies to produce food for the army and to stave off widespread starvation. It was obviously more concerned with how to feed the army, since rural peasants were expected to meet most of their own food needs. The government made extra demands on rural farmers, who were also struggling to survive the war and for which the Biafran government had no alternative. These programs were desperate measures to increase the available food in the region, but the results of these agricultural campaigns were limited. Apart from a few encouraging instances as indicated in Table 1 below, official programs did not improve the food situation significantly.

Table 1

B.D.C Crash Programme on Food Crop and Livestock Production for 1968/69: Summary by Projects

\begin{tabular}{|c|c|c|c|c|c|}
\hline Projects & Acre & $\begin{array}{c}\text { Yield } \\
\text { (tons) }\end{array}$ & $\begin{array}{c}\text { Revenue } \\
(\mathfrak{f})\end{array}$ & Cost (£) & $\begin{array}{c}\text { Profit/ } \\
\text { Loss (£) }\end{array}$ \\
\hline Maize & 10,371 & 13,911 & 349,020 & 345,760 & $+3,260$ \\
\hline Rice & 500 & 446.5 & 27,750 & 20,000 & $+7,750$ \\
\hline Onion & 20 & 60.0 & 3,360 & 1,766 & $+2,394$ \\
\hline Tomatoes & 10 & 7.5 & 2,100 & 1,280 & +820 \\
\hline Totals & 10,901 & & $£ 382,230$ & $£ 368,806$ & $£ 14,224$ \\
\hline
\end{tabular}

Source: NAE ESIALA 63/1/70, File no. Sec/217 vol. 1 'B.D.C. Crash Programme on Food'. 
The BDC rice projects at Ameke Abam, Ndi Oji, Eket, and Elele lost about $£ 16,630$ from an estimated investment of about $£ 85,869$ (NAE ESIALA 63/1/70-SEC/217 vol. 1). The BDC also lacked the necessary funds and agricultural inputs to execute some of its projects. Maize was not available in quantities that could enable the government to meet its set goals. Yet the war conditions and acute food shortages that emerged in 1968 compelled government officials to stress the need for small farmers to produce yams. However, seed yams and suitable land for yam production were not readily available (Ibid.). In February 1968, the Director of the Food Production Directorate wrote to the Chairman of the BDC on the need to meet the yam requirements of Biafra:

I wish to address you especially on the need to grow yams regardless of what economic argument we may have had against doing so under the emergency food programme. Recent developments and disturbances, especially in the yam growing areas, point to the unhappy fact that we shall be facing acute shortage of this important food commodity this year. Some of this year's harvests have been destroyed through enemy action. People have moved out en mass from the disturbed areas and so are most unlikely to cultivate their farms with this crop this year. We are doing all we can to encourage refugee farmers to grow crops in their temporary homes. But this plan may not materialise (NAE ESIALA 63/1/70-SEC/217 vol. 1).

While the government struggled to produce enough to feed the army, the declining fortunes of Biafra made it extremely difficult to practice any meaningful agriculture. The war conditions prevented the $\mathrm{BDC}$ and the Directorate of Food from harvesting some of the crops when parts of Biafra came under the control of the federal troops (Ibid.). In July 1968, for example, the BDC was forced to abandon its maize crops and, the palm and rubber estates at Elele when federal troops retook over the areas. The deputy controller of the BDC summarized the situation in these words:

...It is felt that our frantic efforts now seem belated. The fast deteriorating military situation around Elele and Etche areas if not quickly arrested, will definitely make it impossible for us to harvest our maize in Abara, Odagwa, Elele Rubber and Elele Oil Palm Estates (Ibid.). 
Another program was the Biafra Land Army Food Programme. The Biafran government called on Igbo farmers and rural dwellers to support the war effort by producing more food for themselves and to supply the army. In an address at the Biafran Agricultural Seminar held on 17 January 1969, Ojukwu expressed concern about the food supply problem given the contraction of the area under Biafran control (Ojukwu 1969: 66). The Land Army sought to mobilize the population for food production, except for those who were involved in the fighting (NAE ESIALA 63/1/70-Sec/217 vol. 1). The Land Army consisted of youths between the ages of 12 and 35. They were expected to undergo some military training to facilitate their agricultural activities. Older men up to 50 years of age were expected to join in some of its activities such as bush clearing (Ibid.). It encouraged villages to initiate farming activities in the local communities for which the government provided advisory services. It also endeavoured to establish poultry production and emergency fish pond construction to solve the protein needs of the people in addition to attempting to increase the production of maize, rice, sweet potatoes and yams (Ojukwu 1969: 66).

Like many war-time measures, however, the Land Army programme faced enormous logistic and bureaucratic problems. Its activities overlapped those of the Food Directorate, especially the Win-theWar food farm schemes. ${ }^{4}$ The apparent duplication of the activities of the other agencies generated unnecessary competition. One public figure asserted that there was 'confusion in villages caused by so many agencies campaigning for the adaptation of specific production projects by the various communities' (Ojukwu 1969: 66). The programme deprived many villagers of their means of livelihood. The boys in the Land Army terrorized villages and forced villagers to give up whatever food they had.

\section{BDC CASH CROP PROGRAMMES}

The agricultural program in Biafra benefited directly from the plantation schemes of the former Eastern Region. The BDC inherited about 154,000 acres in the 27 tree crop plantation schemes established by the ENDC (NAE ESIALA 63/1/70-SEC/217 vol. 1, 1968). While food production was the focal point of state agricultural enterprise, the existing cash crop projects provided the impetus for maintaining these plantations and farm settlements. About 82,000 acres were already under oil palm, rubber, cocoa, cashew, and coconut plants (Ibid.). It was the government's view that the BDC should consolidate what 
was already planted for three important but related reasons. First, it was recognized that the capital required for the development of the remaining parts of the estates was not readily available. Second, the Biafran government could not afford further investment in the plantations because its priority was to feed the army and the population. Third, food crops provided quick cash revenue.

\section{THE CIVIL WAR AND PRODUCTION: AN OVERVIEW}

Like any war, the civil war affected both the national and regional economies. However, its impact was devastating for rural Igboland. The war disrupted cash crop production, especially palm produce export, which had historically been the main source of income for Igbo peasants. Trade and commerce in general also diminished due to the general insecurity and the mobilisation of large numbers of men into the army. The export of palm produce declined substantially due to the civil war as the Table below shows, which continued to fall considerably after the civil war.

Table 2

Major Agricultural Exports in Nigeria 1960-1983 ('000 tons)

\begin{tabular}{||c|c|c|c|c|c|c||}
\hline Year & Cocoa & $\begin{array}{c}\text { Palm } \\
\text { oil }\end{array}$ & $\begin{array}{c}\text { Palm } \\
\text { kernels }\end{array}$ & $\begin{array}{c}\text { Ground- } \\
\text { nut }\end{array}$ & Rubber & Cotton \\
\hline 1960 & 154 & na & 418 & 379 & 57 & na \\
\hline 1961 & 184 & 165 & 411 & 614 & 55 & na \\
\hline 1962 & 195 & 118 & 367 & 681 & 60 & na \\
\hline 1963 & 175 & 126 & 398 & 768 & 63 & na \\
\hline 1964 & 197 & 134 & 394 & 763 & 66 & 25 \\
\hline 1965 & 255 & 150 & 416 & 716 & 68 & 14 \\
\hline 1966 & 190 & 143 & 394 & 810 & 70 & 15 \\
\hline 1967 & 224 & 16 & 162 & 742 & 48 & 33 \\
\hline 1968 & 206 & 3 & 159 & 918 & 54 & 14 \\
\hline 1969 & 171 & 8 & 172 & 784 & 56 & 14 \\
\hline 1970 & 193 & 8 & 182 & 536 & 59 & 28 \\
\hline 1971 & 267 & 20 & 238 & 183 & 51 & 22 \\
\hline 1972 & 228 & 2 & 209 & 105 & 41 & 1 \\
\hline 1973 & 211 & - & 137 & 199 & 49 & 8 \\
\hline 1974 & 180 & - & 185 & 30 & 59 & - \\
\hline 1975 & 198 & - & 173 & - & 57 & - \\
\hline 1976 & 231 & - & 472 & - & 39 & - \\
\hline 1977 & 165 & 9 & 184 & 8 & 18 & - \\
\hline 1978 & 205 & 8 & 58 & - & 29 & - \\
\hline
\end{tabular}




\begin{tabular}{||c|c|c|c|c|c|c||}
\hline Year & Cocoa & $\begin{array}{c}\text { Palm } \\
\text { oil }\end{array}$ & $\begin{array}{c}\text { Palm } \\
\text { kernels }\end{array}$ & $\begin{array}{c}\text { Ground- } \\
\text { nut }\end{array}$ & Rubber & Cotton \\
\hline 1979 & 155 & 1 & 104 & - & 29 & 22 \\
\hline 1980 & 135 & 1 & 77 & 0 & 41 & 0 \\
\hline 1981 & 143 & 0 & 124 & 0 & 21 & 0 \\
\hline 1982 & 150 & 2 & 50 & 0 & 17 & 0 \\
\hline 1983 & 228 & 0 & 70 & 0 & 8 & 0 \\
\hline
\end{tabular}

Sources: Iyegha 1988: 35. Based on Federal Office of Statistics, Economic Indicators, Lagos, Nigeria (various issues), Federal Office of Statistics, Annual Abstract of Statistics, Lagos, Nigeria (various issues), and Federal Office of Statistics, Review of External Trade (Lagos: Nigeria 1979-1983).

The general decline due to the war affected crops such as rice, yams, and cassava. Prior to the civil war, for example, maize production in Nigeria was estimated to be 1.1 million tons, of which the Eastern Region contributed about 153,000 tons. Despite some recovery in maize production, its national production declined during the war according to the economic Survey of Nigeria for 1970/1971.

At the end of the war, several factors combined to herald an especially difficult time for rural farmers. An important long-term implication of the war on Igbo agriculture was the near disappearance of yams and cocoyams - the icons of Igbo agriculture. Many people did not go back to farming simply because they did not have the crops to plant.

Many Igbo people did not benefit from the rehabilitation programme of the federal government at the end of the civil war. ${ }^{5}$ While many public servants went back to their work, there was no attempt to rehabilitate Igbo migrants, most of whom lost their properties when the war broke out. ${ }^{6}$ The condition of the rural areas at the end of the war generated a wave of migration from Igboland. The nature and reasons for the new migratory trend differed from those in the past. Lacking cash and the most important crops in their agrarian economy, many rural farmers moved out in large numbers as migrant farmers or traders after the civil war. The migration in this era alleviated the poverty that confronted many Igbos after the war.

Migration contributed substantially to the revival of the rural economy. The highly-populated areas of Mbaise, Owerri and Ikeduru continued to be the main source of migrants in this period. Cash remittance was important to support families at home. Migrants who returned to the villages also established small-scale trading businesses, while some invested in oil palm plantations and poultry farms. How- 
ever, the short- and long-term migration, which many rural farmers embarked upon after the war, was also a proximate cause of a series of problems in rural agriculture. The lack of attention given to agriculture accounted for low productivity in the agricultural sector after the war. Migration also had a deleterious effect on the cultural and social organisations that sustained agriculture. Those people who remained in the rural areas, especially women, were over-burdened. The absence of men hurt social coherence and weakened important labour networks and the enthusiasm for agriculture generally. What are the implications of migration for Igbo agriculture and agricultural sustainability? The historical development of agriculture shows that there is a strong link between migration and land use patterns in many parts of Igboland. As rural farmers became more interested in off-farm employment, they reduced land intensification and increased fallow periods.

One of the most enduring transformations in the rural economy was gender related. The participation of women in long distance trading during the war has become an important feature of the Igbo society. Women actively traded across enemy lines and supplied the bulk of the foodstuffs consumed in Biafra. 'Ahia Attack', as the trading during the war was known, stimulated fundamental social and economic change with far-reaching implications. The increased participation of women in trade after the war continued to diminish agricultural labour. This used to be a matter of shame, but attitudes about it have now changed. The social constraints that inhibited women's movement outside the home changed because their role in the survival of the household became very important during the war.

The civil war marked a watershed in the course of Nigerian development, but, as Michael Watts suggests, Nigeria emerged in the 1980 s as a robust and outspoken member of a semi-industrial, capitalist periphery from its pre-war mercantile basis and wholesale dependence on several agrarian export commodities (Watts 1983: 486). The basis of the Nigerian economy which relied on the export of commodities produced by the rural population changed dramatically in the 1970 s due to the increased importance of the petroleum industry.

\section{OIL BOOM, AGRICULTURE, AND THE NIGERIAN} ECONOMY

In 1964, Nigeria earned only about 250 million dollars in oil revenue (Myers 1990: 94). However, beginning in 1970, the Nigerian economy was significantly transformed by the expansion of the petroleum in- 
dustry. The huge growth in oil revenue after 1973 permitted the reconstruction of a war-devastated economy and provided the means to support increased state centralisation at the federal level (Watts 1983: 469). The proliferation of states further deepened local and regional economic dependence 'on a kitty of centrally administered oil revenue, which naturally fluctuated in accordance with prevailing petroleum prices and the demand for Nigerian oil in a world economy' (Ibid.).

Michael Watts and Paul Lubeck have argued that the state expanded, centralized, and increased its direct involvement in production (Watts and Lubeck 1983: 103-144). The emergence of oil permitted a measure of autonomy from foreign aid and the emergence of a powerful centralised bureaucracy (Ibid.). The petroleum boom brought new opportunities, and the wealth created by the oil industry made the state and some people wealthy. But it was also a period of ambivalence. The resultant inequality and inflation that it generated in the 1980s led to devastation of the economy and created rural and urban poverty. The rapid expansion of the oil industry in the 1970s increased the revenue base of the country outside the agricultural sector. The combination of national and international actions, culminating in the formation of the Organization of Petroleum Exporting Countries (OPEC), led to sharp increases in oil prices between 1971 and 1980. Additionally, the Arab-Israeli war in 1973 and the oil embargo to Western countries that supported Israel caused dramatic increases in oil prices. The Iranian Revolution of 1979 led to another oil shock, and oil prices rose by over 130 per cent. The occasional windfall continued into the 1990s. These crises brought huge revenue to Nigeria. Oil prices rose from $\$ 3.78$ per barrel in October 1973 to $\$ 14.69$ per barrel by the beginning of 1974 (Okolie 1995: 98). The export boom led to an increase of nearly 10 per cent GDP annual growth during the 1970s and early 1980s (Kolko 1988: 37). Revenue went from a low 411 million dollars in 1970 to 26.62 billion dollars in 1980 (International Financial Statistics 1980: 288).

The dramatic rise in global oil prices coincided with the Second National Development Plan, 1970-1974. Agriculture, mining and manufacture were projected to contribute 44.2 per cent, 13.4 per cent and 12.4 per cent respectively to GDP. The actual contribution to GDP, however, was only 24.7 per cent for agriculture, 45.1 per cent for mining and 4.8 per cent for manufacturing. The importance of crude oil to the economy from this period is reflected in the significant increases in export quantity and its contribution to national revenue. 
Petroleum Production and Revenue

(1975 = 100 barrels/day and 100 million naira)

\begin{tabular}{|c|c|c|c|c|}
\hline Year & $\begin{array}{c}\text { Index of } \\
\text { crude petro- } \\
\text { leum pro- } \\
\text { duction } \\
\text { (million b/d) }\end{array}$ & $\begin{array}{c}\text { Index of } \\
\text { crude pe- } \\
\text { troleum } \\
\text { export (mil- } \\
\text { lion naira) }\end{array}$ & $\begin{array}{c}\text { Index of vol- } \\
\text { ume of crude } \\
\text { petroleum } \\
\text { exports } \\
\text { (million b/d) }\end{array}$ & $\begin{array}{c}\text { Index of } \\
\text { crude petro- } \\
\text { leum export } \\
\text { price } \\
\text { (naira) }\end{array}$ \\
\hline 1973 & 115 & 1,933 & 116 & 33 \\
\hline 1974 & 126 & 5,665 & 128 & 94 \\
\hline 1975 & 100 & 4,593 & 100 & 100 \\
\hline 1976 & 116 & 5,894 & 116 & 108 \\
\hline 1977 & 117 & 7,046 & 120 & 122 \\
\hline 1978 & 106 & 6,033 & 108 & 118 \\
\hline 1979 & 129 & 10,034 & 130 & 174 \\
\hline
\end{tabular}

Source: Watts 1983: 474.

As government revenue increased, the state adjusted to the new conditions that emerged from the expanding oil sector. Indicative of this new power at the federal level was the allocation of a major part of the revenue to the federal government. The allocation to the states also grew from 323.8 million naira in 1974 to 2,534 million in 19791980 (Watts and Lubeck 1983: 108). The growth in the Nigerian economy was rapid, with an annual GNP growth of 7.4 per cent between 1970 and 1979. This period, however, was qualitatively different from the pre-1970s. The growth in the oil sector was accompanied by a significant sectoral transformation. These changes in sectoral composition reflected 'not simply a growth in non-farm activities but a stagnant agrarian economy' (Ibid.).

What followed increased revenue was massive expansion of infrastructure and industry. The increase in oil revenue was followed in many parts of the country by an extensive growth in the urban population and the rapid growth of an industrial labour force. It was also followed by the commoditisation of urban social relations, a sharp upturn in the numbers of a disenfranchised and militant 'floating population', and new waves of rural migrants (Watts 1983: 467). At the same time, the expanding urban sector demanded semi-skilled labour for the construction industry and other service sector jobs. This development was important in two ways to the Igbo countryside, which experienced a population growth rate of over 3.0 per cent but produced few jobs. The Igbo responded to the urban economic growth and the opportunities 
it afforded them. It was by diversifying household incomes that the Eastern Nigerian societies could deal with decreasing land and low productivity in rural agriculture.

Table 4

Sectoral Composition of Nigerian Output for Selected Years, 1960-1975 (in percent)

\begin{tabular}{|l|c|c|c|c|}
\hline \multicolumn{1}{|c|}{ Sector } & $\mathbf{1 9 6 0}$ & $\mathbf{1 9 6 3}$ & $\mathbf{1 9 7 0}$ & $\mathbf{1 9 7 5}$ \\
\hline Agriculture & 64.1 & 55.4 & 45.8 & 28.1 \\
\hline Oil and Mining & 1.2 & 4.8 & 12.2 & 14.2 \\
\hline Manufacturing & 4.8 & 7.0 & 7.6 & 10.2 \\
\hline $\begin{array}{l}\text { Building and } \\
\text { Construction }\end{array}$ & 4.0 & 5.2 & 6.4 & 11.3 \\
\hline Others & 25.9 & 27.6 & 30.0 & 36.2 \\
\hline & 100.0 & 100.0 & 100.0 & 100.0 \\
\hline
\end{tabular}

Source: Watts and Lubeck 1983: 110.

Eastern Nigeria was in a unique position, because most of the oil is in the region. The expansion of the oil industry induced large-scale migration from the region. At the same time, the agricultural sector suffered loss of labour and witnessed an increase in women's burden in production. But the emphasis on the non-agricultural sector continued at all levels of the economy as governments and individuals made choices that intensified the agricultural crisis at the national level but also ameliorated its effect for some rural dwellers. In rural Igboland, for example, where the average holding had declined considerably, the economic opportunities the non-agricultural sector offered peasants brought some relief.

Average Size of Farm and Holding 1984/85

\begin{tabular}{|c|c|c|c|c|c|c|}
\hline State & 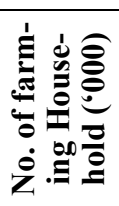 & 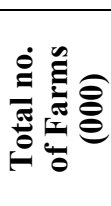 & 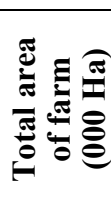 & 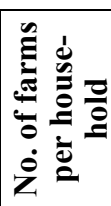 & 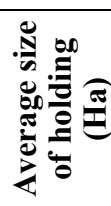 & 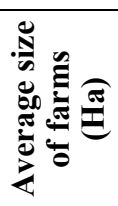 \\
\hline Anambra & 565 & 1,363 & 137 & 2.41 & 0.25 & 0.10 \\
\hline Imo & 634 & 1,529 & 109 & 2.41 & 0.18 & 0.07 \\
\hline $\begin{array}{l}\text { National } \\
\text { Average }\end{array}$ & 6,066 & 12,141 & 6,608 & 2.00 & 1.14 & 0.57 \\
\hline
\end{tabular}

Source: Federal Office of Statistics 1987: 16. 
As the petro-economy expanded, a new entrepreneurial class, 'contractors', emerged more clearly than before the 1980s. They engaged in the booming supply business and used their profits to invest in trading. Others used their salaries to invest in agriculture. In Imo State, they leased land and hired labour to produce cassava in areas such as Ohaji and Egbema. But the situation of the generality of peasants remained precarious because they lacked the land, labour and cash to invest in agriculture.

The general outlook, however, was one of decreasing food and agricultural productivity. The interests of the Nigerian government in agriculture flagged considerably, shifting to the more lucrative oil sector. The change in sectoral base of government revenue was responsible for the decline in agriculture and the increased reliance on imported foodstuffs.

Table 6

Share of Food in Total Import Value, 1971-1987 (Million Naira)

\begin{tabular}{|c|c|c|c|}
\hline Year & Total imports & Food imports & \% Share of food \\
\hline 1971 & $1,069.1$ & 88.3 & 8.2 \\
\hline 1972 & 990.0 & 95.8 & 9.7 \\
\hline 1973 & $1,241.1$ & 128.0 & 10.3 \\
\hline 1974 & $1,737.3$ & 154.8 & 8.9 \\
\hline 1975 & $3,721.5$ & 297.9 & 8.0 \\
\hline 1976 & $5,148.5$ & 440.9 & 8.0 \\
\hline 1977 & $7,093.7$ & 786.4 & 10.4 \\
\hline 1978 & $8,217.1$ & $1,020.7$ & 12.4 \\
\hline 1979 & $6,169.2$ & 952.4 & 15.4 \\
\hline 1980 & $6,217.1$ & $1,049.0$ & 12.8 \\
\hline 1981 & $12,602.5$ & $1,820.2$ & 14.4 \\
\hline 1982 & $10,100.2$ & $1,642.2$ & 16.0 \\
\hline 1983 & $6,107.5$ & $1,176.7$ & 19.0 \\
\hline 1984 & $7,178.3$ & $1,052.1$ & 14.7 \\
\hline 1985 & $7,662.6$ & $1,199.8$ & 16.988 \\
\hline 1986 & $5,983.6$ & 803.1 & 13.41 \\
\hline 1987 & $17,861.7$ & $1,573.7$ & 8.811 \\
\hline
\end{tabular}

Source: Government of Nigeria: Know Nigeria Series No. 1: Towards SelfSufficiency in Food (Lagos: Federal Ministry of Information, 1991) and Central Bank of Nigeria, Economic and Financial Review (various years).

By 1974, Nigeria's food imports bill had tripled, and it continued to increase into the 1980s. Towards the end of the 1980s, Nigeria's 
food imports had increased from 509.79 million naira in 1964 to 9 , 658.10 million naira. And between 1973 and 1980, there was an overall annual decline in agricultural production, while the GDP growth rate was more than halved (Morgan and Solarz 1994: 59). At the same time, revenue slumped to 13.1 billion dollars between 1981 and 1982, and continued to reduce to approximately 7 billion dollars in 1988 .

The crisis in agriculture in the last three decades is linked to the transformation of the Nigerian economy and a dependence on oil revenue from the 1970s. The ruinous inflation that accompanied the oil wealth was reflected in the inability of peasants to survive on what they produced. As subsistence production became radically undermined by the petroleum economy, peasants and villagers suffered dire consequences. Despite the boom, the rural and agricultural landscapes and their associated problems remained relatively unchanged. As Watts notes, some classes benefited materially from the commodity boom, as measured by the consumption of purchased imports, "but the majority of the urban and rural poor found any hard-won gains rapidly eroded by inflation' (Watts 1983: 483).

\section{GOVERNMENT RESPONSE}

The post-oil boom political economy of Nigeria also reflects the sluggish performance of agriculture, especially export production. Investment in agriculture fell from 7 per cent of the budget in 1971 to 4 per cent in 1981 (Myers 1990: 94). In view of the crisis in the agricultural sector, the federal government intervened at different historical times through programs that had national and regional consequences for agriculture. With about 57 per cent of the allocation to agriculture unspent, the Gowon administration (1966-1975) interpreted this as indicative of a fundamental defect in the design and implementation of agricultural programs. A substantial part of the remaining money was allocated to government projects such as farm settlements, irrigation schemes and plantation projects for cash crop production. However, there was no direct support for peasant farmers, who contributed over 95 per cent of both the export and domestic productions. The government's support for farmers in the form of credits went to a few commercial farmers and bureaucrats disguised as farmers. Under these conditions, many peasants abandoned their farms to seek other forms of employment.

Given the declining contribution of agriculture to the national economy at the end of the Second National Development Plan period, the Gowon regime recognized that dependence on oil was a vulnerable 
economic strategy. For this reason, agriculture received high priority during the Third National Development Plan period, 1975-1980. The plan also recognized the need to check rural-urban migration through a balanced development agenda for both the rural and the urban sectors, but the continued expansion of the oil sector and the opportunities it provided for employment and trade undermined the agricultural sector.

The major intervention to deal with the agricultural crisis in the country came in 1976, when the Obasanjo government launched the Operation Feed the Nation (OFN) programme. The objectives of the OFN program included the mobilization of the nation towards selfsufficiency and self-reliance in food production. But these objectives were not achieved. The program collapsed for various administrative and logistic reasons. Political expediency inhibited its successful implementation. As a program designed to make fertilisers available to farmers through the various ministries of agriculture, the scheme faced many logistic problems. Fertiliser often arrived so late in some areas that it could not be applied to crops. Storage facilities provided under the program were grossly inadequate. In many cases, bureaucrats hijacked the fertilisers and resold them to peasant farmers at prices that many could not afford. Unfortunately, the OFN did not target the peasants who had been the backbone of the country's agricultural production. The political elite usurped the gains that would have been made. Because the government did not deal directly with peasants, they did not comply with the wishes of the government. All this needs to be seen against the massive importation of food, which tripled by the end of the OFN program in 1979.

The state also intervened in the customary land tenure systems in Nigeria through the implementation of the Land Use Decree in 1978. The decree sought to eliminate the problems associated with traditional land tenure systems. It also aimed to create a uniform tenure system and to eliminate any tenure arrangements that inhibited large-scale agricultural development. Farming became the favourite part-time occupation for the military elite. The decree created opportunities for the military elite and bureaucrat elite to take land from peasants. At the state level, it vested authority over land in the governor of each state. Although most of the rural areas remained relatively unaffected by the decree, communities located on the periphery of the urban centres had lost their land to urban development.

In response to the crisis, the government began to accord very high priority to agriculture. The federal government embarked on the 
development of irrigated farms in the northern parts of the country. This agenda was vigorously pursued in the Fourth National Development Plan, 1981-1985, as a means of expanding local food production and basic raw materials for industries under President Shehu Shagari's 'Green Revolution' (GR) programme launched in May, 1980.

The Green Revolution program called for an accelerated increase in agricultural production through removal of the constraints to increased production and the provision of agricultural input and extension services to farmers. To achieve these objectives, the government established the River Basin Development Authorities and Integrated Agricultural Development Projects. There were eleven River Basin Development Authorities and nine Agricultural Development Projects established throughout the country including the Anambra-Imo River Development Authority. The projects were attempts to increase the production of rice, sugarcane, millet, sorghum, maize, wheat, cassava, and yams. The irrigation policy aimed to develop a system of multiple cropping in the northern arid zones of minimal annual rainfall. While the government allocated a substantial amount of 8.828 billion naira to agriculture in this plan period, the legacy of incompetent management, corruption, nepotism and lack of adequate feasibility studies hampered the chances of success. Like the OFN, the Green Revolution program ignored the peasant producer. The Green Revolution program achieved very little due to weak and corrupt leadership (Bamisaiye 1985).

Irrigation projects did not revolutionize agriculture in the country. Rather, they created the problems of peasant relocation and land alienation on a massive scale. About 31,000 people were relocated because of construction of the Bakolori and Sokoto River Dams (Siddle and Swindell 1990: 152). These projects did not increase food production. Government incentives also benefited only commercial farmers, who often diverted agricultural credits to other uses. The location of some of the agricultural projects was politically motivated. For example, the establishment of irrigation projects in parts of northern Nigeria was motivated by the need to distribute some of the benefits of the oil boom of the 1970s.

The government's 'quick fix' attitude towards agriculture did not reflect its overall development ideology of rural development. The policies of the government reveal the inherent contradiction in state-peasant relationship (Berry 1993: 182). The failure to provide farmers with adequate incentives and support to permit wide-spread 
adaptation of improved techniques led to the failure of government agricultural projects.

The creation of new states in 1976 was accompanied by more reforms at the state level. Like its predecessors, the new states continued to attach a lot of importance to agriculture. At the top of the policymaking apparatus at the state level was the Ministry of Agriculture and Natural Resources. One of the most important projects for agricultural development in Nigeria was the Agricultural Development Programmes (ADP). The ADPs, which started in 1974, were federal programs implemented at the state level. These corporations were charged with the production and processing of agricultural products. In Imo State, for example, the ADP produced maize, cassava, and horticultural crops, including budded citrus and pineapple, all of which had become highly commercialized (Imo State 1984: 17). The ADP also engaged in export crop production. The ADP's responsibility was the small-scale farmers' needs. However, G. Williams (1981) has noted that the benefits 'accrued to the rich rather than the poor', and that 'some projects have excluded the poor from access to productive resources and redistributed the assets and incomes to the rich.' These included oil palm projects at Ohaji, Ozuitem, Nkporo, Ulonna North and South, and rubber plantations at Obitti, Emeabiam, Ameke Abam and Ndioji Abam.

The Corporation's projects did not revolutionize agriculture in the region. The commission of inquiry set up to review the activities of the ADP in 1980 found that the 188.4 hectares cashew plantation at Mbala, was unprofitable as an economic venture. Only 10 per cent of 4,092 hectares of mature rubber were being tapped in 1980. The oil palm development projects did not increase the overall production from the region. The pioneer oil mills (POM) located in Imo State, for example, could not even break because of its structural rigidity, paucity of palm fruit supply and the salary/wage bill that has been too heavy for the small volume of business the POM handles.

In the final analysis, the food crop project, which was fully funded by the state, did not fare better than earlier projects. A combination of political consideration and managerial misappropriation thwarted the ability of the project to make any impact. The establishment of the rice project at Ugwueke, the Commission of Inquiry argued, was unprofitable because it appeared to be politically motivated.

Despite the increased involvement of the state in agriculture, rural peasants did not respond favourably. In Imo State, for example, the total area under cultivation fell from 203,000 hectares in 1976 to 52,000 in 1981, representing an annual decline of 32 per cent (Imo 
State of Nigeria: ISADAP). The output of yam in 1981 was 22,000 tons, representing a 39 per cent decrease from the 1976 output. Likewise, the output of cassava fell by 78 per cent between 1976 and 1981 . While these data may be unreliable, they are indicative of a food crisis and dramatize the rate of agricultural involution in rural Eastern Nigerian society.

\section{THE ERA OF STRUCTURAL ADJUSTMENT PROGRAMMES, C. 1987-1995}

Nigeria experienced a degree of prosperity from oil revenue before the mid-1980s. However, this prosperity was short-lived. The dramatic fall in oil prices beginning in 1982 affected the national economy. While the rural areas were not directly affected by the oil wealth, their economic conditions were directly affected by the dependence on oil and the transformation of the country. As the economy faced a recession and an increase in indebtedness, the changing fortunes of the state also affected the rural economies. The loss in revenue led to the introduction of painful austerity measures. The World Bank and the International Monetary Fund stepped in to restore fiscal discipline through a set of macroeconomic policies designated as Structural Adjustment Programmes (SAP). These measures culminated in the implementation of the programme by the Babangida regime in 1986.

The aims of SAP were debt recovery in the short term and poverty reduction through economic growth in the long term. The liberalization of the economy involved the elimination of stimulus programmes, the abolition of subsidies, a reduction in price control and export promotion, devaluation of the currency, privatization of state owned industries and reduction in public spending. This resulted in massive lay-offs of workers and overall economic problems. Within Igboland, these measures came to be known as ota na isi (knock on the head) because of the hardship that followed their introduction.

The implementation of SAP led to an increase in rural poverty and in the prices of all necessities. Although the cost of living increased enormously, real wages fell under the SAP. Household consumption data collected between 1980 and 1996 and agricultural census information collected in 1993 and 1994 show a linkage between the agricultural sector and poverty (FAO 1999). In the mid-1990s, about 67 million people, or about 65 per cent of the population, were identified as poor. A poverty assessment (PA) study carried out in parts of Nigeria shows that in 1985,87 per cent of the core poor was rural agricultural households. In 1992, the very poor represented 67 per cent of the rural dwellers (Ibid.). In Igboland, as in other parts of rural Nigeria, 
peasants lacked basic agricultural inputs and continued to experience declining agricultural productivity. However, the relatively low level of poverty in southeastern Nigeria, as shown in Table 7 below, indicates the importance of non-agricultural income-generating activities.

Table 7

Poverty Incidence of Farmers by Regions and Gender, 1993/94

\begin{tabular}{|l|c|c|c|}
\hline \multicolumn{1}{|c|}{ Region } & Extreme Poor & Moderate Poor & Non-Poor \\
\hline North East & 58.15 & 27.75 & 23.19 \\
\hline North West & 59.19 & 24.30 & 16.15 \\
\hline North Central & 47.09 & 27.23 & 25.68 \\
\hline South East & 36.42 & 31.78 & 31.80 \\
\hline South West & 27.21 & 34.66 & 38.13 \\
\hline South South & 38.75 & 35.57 & 25.69 \\
\hline ALL & $\mathbf{4 8 . 0 6}$ & $\mathbf{2 8 . 7 5}$ & $\mathbf{2 3 . 1 9}$ \\
\hline Male Holder & 48.59 & 28.60 & 22.81 \\
\hline Female Holder & 42.82 & 30.19 & 26.99 \\
\hline
\end{tabular}

Source: Nigeria, Poverty and Agricultural Sector in Nigeria: Poverty Incidence of Farmers by Region (Abuja: Federal Office of Statistics, 1999), 27.

SAP had a fundamental impact on household survival strategies. Marital status, a variable played an important role in determining how the rural population responded to economic crisis under SAP. There was a significant increase in women's control over household resources and income since SAP. Many households became increasingly dependent on female income, not only in female-headed households but also in many marginal rural households where female incomes make significant contribution to total household income. Women in many rural households are also taking more control over incomegenerating resources, especially palm produce. The effects of these changes on household survival strategies have been increasingly apparent in recent times.

\section{RURAL SURVIVAL STRATEGIES}

Deborah Bryceson has shown that African peasants are currently embarked on a dual strategy of experimenting with non-agricultural income earning while retaining the security of an agricultural subsistence fall-back (Bryceson 1999: 28). For many rural dwellers, there is a psychological dependence on agriculture, despite the importance of non-agricultural income-generating activities in the society (Bryceson 1999: 31). The 1970s witnessed a remarkable increase in the number 
of Igbo people engaged in non-farming activities. Despite the importance of non-agricultural income, Igboland has remained largely agrarian. Subsistence agriculture remains an indispensable means of circumventing the relentless treadmill of having to earn cash to provide one's basic needs (Potts and Mutambirwa 1998). This perception remains strong in the psyche of the rural population and explains their persistence in farming. In a 1999 survey, 52 per cent of respondents combined agriculture with non-agricultural activities, and only 26 per cent considered non-agricultural activities as their primary occupation (Chukwuezi 1999).

The persistence of rural farming reflects the expectation that one should meet part of one's subsistence from one's own farm. For many rural dwellers, the combination of farming with other economic activities reduces the likelihood of total economic failure. The persistence of the rural population in farming, therefore, is not only an action driven by economic rationalism, but also has much to do with their identity - as persons who do not have to depend on the market for subsistence.

However, the persistence in farming has followed a different trajectory since the 1970s. The changes have been most pronounced in the adaptation of new methods of production, emphasis on the production of certain crops, and changes in dietary habit as well as gender relations. This is most evident in the adaptation of cassava as food crop. In general, cassava provides about 40 per cent of the calories consumed in Africa, a third of the total staple produced in sub-Saharan Africa and about 70 per cent of the daily calorie intake of over 50 million people in Nigeria. Its starchy, tuberous roots provide a valuable and cheap source of calories in developing countries. The leaves and tender shoots are also consumed as vegetables in other parts of subSaharan Africa. Available agricultural statistics show that cassava is the most widely grown staple in Eastern Nigeria. This appears to be the case with many rural sub-Saharan African societies.

Cassava production in Africa is growing more rapidly than in other regions. The spread of cassava in different African ecological systems and its adoption as a staple occurred for distinct reasons. The East African highlands adopted cassava in response to population increases and the need to maximize land productivity. The FAO reports that the increased production of cassava has reduced hunger, particularly in western African countries. Indeed, until the twentieth century cassava was a crop of little importance except in the Owerri 
areas of Eastern Nigeria. Cassava was previously a famine relief staple and mostly regarded as food for the poor. For both ecological and other factors, however, cassava has become one of the most important food crops in Igboland. Opinions varied on why farmers adopted cassava in place of traditional staple food crops. Nevertheless, there is a consensus that cassava has many advantages over other crops. It has been estimated that a hectare of cassava can feed fifty and seventy persons per annum. Yams and other food crops have failed to provide similar returns in recent years because of decreasing soil fertility and soil degradation.

The value of cassava in periods of agricultural crisis was shown both during the First World War and during the famine that followed the influenza pandemic between 1918 and 1919. Don Ohadike argues that the war and the famine that followed the influenza pandemic increased the acceptance of cassava in some parts of Igboland (Ohadike 1981: 203). Two major transformations relating to cassava also took place in the agricultural economy of the Eastern Region in the 1950s. First, cassava became increasingly adopted as a famine relief crop. Second, because it was perceived as inferior to yam, the male prestige crop, cassava became virtually a women's crop for most of the twentieth century. Phoebe Ottenberg, who studied the Afikpo people in the early 1950 s, confirms that the major source of economic change in women's fortunes was the introduction of cassava, the cultivation of which was 'considered beneath the dignity of men' (Ottenberg 1954). While men looked down on cassava, the economic opportunities it afforded to women increased their economic independence and selfesteem. Before the importance of cassava grew among the Igbo, Ottenberg argued, if a woman's husband did not give her food, she 'was in a sorry plight', but the increased importance of cassava meant that she 'could subsist without her husband's support' (Ibid.).

The rural population has increasingly adopted cassava, which thrives well in poor soil, as a staple food. The impressive performance of cassava in the food security arrangements of the Eastern Nigeria reflects the advantages it has over yams and cocoyams and its suitability in the changing agricultural landscape. Cassava has not become a mere addition or substitute to other food crops in Igboland; it has largely replaced them. This is reflected in Table 8 below. 
Summary of Area Planted with Major Crops East-Central State, 1973-1974

\begin{tabular}{|l|c|c|}
\hline \multicolumn{1}{|c|}{ Crop } & Area (Hectares) & Production (Tons) \\
\hline Yam & $102,031.05$ & $1,344,923.03$ \\
\hline Cassava & $138,077.24$ & $1,494,234.96$ \\
\hline Cocoyam & $19,176.05$ & 156.234 .96 \\
\hline Rice & $13,193.98$ & $123,718.31$ \\
\hline
\end{tabular}

Source: Government of East Central State of Nigeria 1977: 35).

\section{CONCLUSION}

This paper examined the impact of the Nigeria-Biafra Civil War, the development of the petroleum industry and state policy on agriculture in Eastern Nigeria. It described how the expansion of the oil industry and state neglect in this period further generated crises in the rural agricultural economy. It also examined how both peasants and state agencies responded to the crisis in agricultural production. The paper further discussed some of the social transformations that occurred in Eastern Nigeria and how these transformations challenged the foundations of indigenous agricultural economy.

It has shown that the civil war as well as the development of the oil sector created conditions that impinged on the fundamental roots of peasant life. The pattern of state intervention in this period, the chapter argued, was conditioned by the political exigencies of the war and the economic transformation that followed the increased revenue from oil. The Biafran State made direct demands on peasants to meet its war-time needs. These demands, however, reflected the attempts by the state to maintain the survival of Biafra and, to feed the army and the citizenry. However, the war created economic and social changes in peasant life that lasted well after the war was over. On the part of the Nigerian State, poorly conceived and incompetently run agricultural programs created a food crisis and a low rate of export productivity never experienced in the history of Nigerian agriculture.

The intervention of the state was characterized by a variety of agricultural programs and broad economic restructuring under SAP. The government provided opportunities for income diversification and imposed constraints on the ability of peasants to continue in their agrarian pursuits. The examination of the nature of state-sponsored agricultural programmes has revealed the contradiction inherent in attempts to improve agricultural production. These programs, the paper argued, have often brought the opposite effect. 
The rural population has responded to the crisis in the agrarian sector by adopting new strategies to ensure food security in the rapidly declining agrarian climate. While some of these survival strategies have been historically important for the Igbo, they were more aggressively pursued after the 1970s as the rural population continued to rely more on non-agricultural pursuits for its survival. These survival strategies, however, continued to be influenced by Igbo social and cultural systems that remained vital in ensuring the survival of many Igbo households amidst crisis. Nevertheless, there continues to be a psychological dependence on agriculture for rural Igbo men and women, despite the importance of non-agricultural income. Yet, these men and women have not often conceptualized the social changes in the societies in terms of gender ideology. In many cases, women lost out in official agricultural programmes, but their economic opportunities also expanded over the period.

Overall, the government's agricultural development projects provide some insight into the problems associated with interventionist approach to rural development in Eastern Nigeria. The evidence shows that the deteriorating condition of agriculture in the region could be traced to state interventionist measures, to the neglect of agriculture, and to the fallout created by these measures. Furthermore, some of the most critical problems seen in this period were of a structural nature, and thus their solutions are even more complex than what has been proposed so far by the government. Problems such as low yields, rural-urban migration and drops in export prices all persist, even long after the government introduced major agricultural reforms.

\section{NOTES}

${ }^{1}$ The policy statements in the reports of the agricultural department from the late 1950s until the formulation of the six-year development plan, 1962-1968, consistently stated increased welfare and productivity as the main goal of government's agricultural policy. The national development plan formed the basis of the various regional development plans for the same period.

${ }^{2}$ The 1954 constitution also introduced important economic reforms in the agricultural sector. From this year, the different regions were given control over the formulation of agricultural policy other than research, which continued to be under the control of the federal department of agriculture.

${ }^{3}$ There was already an estimated 12.4 million people residing in the eastern region before the war started.

${ }^{4}$ Win-the-war food programme was another scheme that the bdc established to produce food on government controlled farms.

${ }^{5}$ The federal government implemented what became known as the $3 r$ (reconciliation, reconstruction, and rehabilitation). 
${ }^{6}$ At the end of the war, punitive damages were imposed on the Igbo. For example, Igbo entrepreneurs were banned from Port Harcourt. This had the effect of denying many Igbo people a successful rehabilitation after the war.

\section{REFERENCES}

Ayittey, G. 1998. Africa in Chaos. New York: St Martin's Press.

Bamisaiye, E. A. 1985. Solving the Food Crisis in Africa: The Role of Higher Education. Journal of African Studies 11 (4): 182-188.

Bello, W. 2008. The Food Crisis: Destroying African Agriculture. Foreign Policy in Focus, June 04.

Berry, S. 1993. No Condition is Permanent: The Social Dynamics of Agrarian Change in Sub-Saharan Africa. Madison: University of Wisconsin Press.

Bryceson, D. F. 1999. Sub-Saharan Africa Betwixt and Between: Rural Livelihood Practices and Policies. ASC Working Paper 43. Leiden, The Netherlands.

Chukwuezi, B. 1999. De-agrarianisation and Rural Employment in Igboland, South Eastern Nigeria. Kano, Center for Documentation and Research and Leiden: African Studies Center Joint Working Paper. Vol. 37.

Cleveland, D. A. 1998. Balancing on the Planet: Towards an Agricultural Anthropology for the Twenty-First Century. Human Ecology 26 (2).

Federal Office of Statistics. 1955. Annual Report on the Department of Agriculture (Central), 1953-1954. Lagos: Government Printer.

Federal Office of Statistics 1972. Rural Economic Survey of Nigeria: Consolidated Report of Crop Estimation 1968/69 to 1970/71. Nigeria, Lagos.

Federal Office of Statistics. 1976. Annual Abstract of Statistics, 1974. Nigeria, Lagos.

Federal Office of Statistics. 1987. Rural Agricultural Sample Survey, 1984/85, 1985/86. Lagos: Federal Office of Statistics.

Government of East Central State of Nigeria, 1977. Report of Rural Economic Survey of the East Central State of Nigeria. Enugu: Government Printer.

Imo State, 1980. Government White Paper on the Report of the Judicial Commission of Inquiry into the ADC, Owerri. Owerri: Government Printer.

International Financial Statistics. 1980. International Financial Statistics. Vol. 33 (12).

Iyegha, D. 1988. Agricultural Crisis in Africa: The Nigerian Experince. Lanham, MD: University Press of America.

Kolko, J. 1988. Restructuring the World Economy. New York: Pantheon Books.

Morgan, W. B., and Solarz, J. A. 1994. Agricultural Crisis in Sub-Saharan Africa: Development Constraints and Policy Problems. Geographical Journal 160 (1): 57-73. 
Myers, G. W. 1990. This is Not Your Land: An Analysis of the Impact of the Land Use Act in Southeast Nigeria. Ph.D. dissertation, University of Wisconsin-Madison.

NAE ESIALA - National Archives Enugu Eastern States Interim Assets And Liability Agency 63/1/70-SEC/217. 1968a. Emergency Food Production. Director, Food Production Directorate to the Chairman, BDC, 5 February, Vol. 1.

NAE ESIALA -National Archives Enugu Eastern States Interim Assets And Liability Agency 63/1/70-SEC/217. 1968b. Emergency Evacuation of Elele Palm and Rubber. M. A. Ntukogu (DC) to Chairman, BDC, 27 July, Vol. 1.

NAE ESIALA - National Archives Enugu Eastern States Interim Assets And Liability Agency 63/1/70-SEC/217. 1969a. Brief Statement on the Land Army. Vol. 1.

NAE ESIALA - National Archives Enugu Eastern States Interim Assets And Liability Agency 63/1/70-SEC/217. 1969b. File no. Sec/217, Report to the Executive Council Committee of Supply. From Food Production Directorate, 23 January, Vol. 1.

Odumegwu Ojukwu, C. 1969. Biafra: Selected Speeches and Random Thoughts of C. Odumegwu Ojukwu. New York: Harper and Row Publishers.

Ohadike Don C. 1981, The Influenza Pandemic of 1918-19 and the Spread of Cassava in the Lower Nigeria: A Case Study in Historical Linkages. Journal of African History 22: 379-391.

Okolie, A. 1995. Oil Revenues, International Credits and Food in Nigeria, 1970-1992. Ph. D. Thesis. Sociology Department, University of Toronto.

Oliver, R. 1999. The African Experience. London: Wiedenfeld \& Nicolson.

Ottenberg, P. V. 1956. The Changing Economic Position of women Among the Afikpo Ibo. In Bascom, W. R., and Herskovits, M. J. (eds.), Continuity and Change in African Cultures (pp. 205-223). Chicago: University of Chicago Press.

Potts, D., and Mutambirwa, C. 1998. Basics are Now a Luxury: Perceptions of Structural Adjustment's Impact on Rural and Urban Areas in Zimbabwe. Environment and Urbanisation 10 (1): 55-75.

Siddle, D., and Swindell, K. 1990. Rural Change in Tropical Africa: from Colonies to Nation States. Oxford: Blackwell.

Tiffen, M. 1976. The Enterprising Peasants: Economic Development in Gombe Emirate North Eastern States, Nigeria 1900-1968. London: Overseas Research Publication.

Timberlake, L. 1985. Africa in Crisis: The Causes, the Cures of Environmental Bankruptcy. London: Earthscan.

Watts, M. 1983. Silent Violence, Food, Famine, and Peasantry in Northern Nigeria. Berkeley: Berkeley University of California Press.

Watts, M. (ed.) 1987. State, Oil and Agriculture in Nigeria. Berkeley: Berkeley Institute of International Studies. 
Watts, M., and Lubeck, P. 1983. The Popular Classes and the Oil Boom: A Political Economy of Rural and Urban Poverty. In Zartman, W. I. (ed.), The Political Economy of Nigeria (pp. 105-144). New York: Praeger.

Williams, G. 1981. The World Bank and the Peasant Problem. In Heyer, J., Roberts, P., and Williams, G. (eds.), Rural Development in Tropical Afri$c a$ (pp. 16-52). London: Macmillan.

World Bank, 1981. Accelerated Development in Sub-Saharan Africa: An Agenda for Action. Washington, DC: World Bank.

World Bank. 1984. Towards Sustainable Development in Sub-Saharan Africa: A Joint Program of Action. Washington, DC: World Bank.

World Bank. 1989. Sub-Saharan Africa: From Crisis to Sustainable Development. Washington, DC: World Bank.

Yakubu, F. 1979. Land Tenure Reform in Nigeria: Implications of the Land Use Decree (Act) for Agricultural Development. Ife Journal of Agriculture 1 (2): 235-257. 